\title{
ETHICS AS A TOOL FOR SUSTAINING BUSINESS DEVELOPMENT AND PROMOTION: A PHILOSOPHICAL APPROACH
}

\author{
Jinadu Abiodun Moses \\ Department Of Philosophy, Faculty Of Arts, Adekunle Ajasin University, \\ Akungba-Akoko, Ondo State, Nigeria
}

Doi: 10.19044/elp.v1no2a13 URL:http://dx.doi.org/10.19044/elp.v1no2a13

\begin{abstract}
The paper examined the importance, relevance and the place of ethics in the society with particular attention on business development and promotion. It believed (the paper) that morality should be given a pride of place while transacting business. It is erroneous in believing that an entrepreneur could be successful without taking into cognizance the concept of morality. Morality, according to this paper, served as a morale booster for any business. No business can thrive without adequate consideration of the relevance of ethics. The paper opined that most of the world's business outfits collapsed because little or no attention was given to morality in the running and operations of those conglomerates. It was on this premise that the paper recommended to all entrepreneurs to always think about the moral standing of their businesses so as to avert any unforeseen contingencies. However, the method of critical analysis was employed in developing this paper. The paper concluded by emphasizing the role morality, which is the hallmark of ethics, played in shaping every business.
\end{abstract}

Keywords: Ethics, Business, Development and Philosophical

\section{Introduction}

Some of the questions people may ask: What has ethics to do with entrepreneurship? Put differently, they may ask what has ethics to do with business because to be an entrepreneur means to run a business at one's own financial risk? Has an entrepreneur anything to do with ethical considerations? After all, business is business. This also implies that ethics is ethics, that both business and ethics belong to two domains of human life which are distinct in themselves; that both have nothing in common; that both are strange bed fellows, and finally that there is no connection between ethics and entrepreneurship. 
While these and other related questions are indeed, good questions, they are at the same time totally misconceived. These questions demonstrate the lack of understanding and appreciation of the role of ethics in human life, in human affairs and in all human endeavours. How ethics play this all important role in human endeavours of any kind including entrepreneurship will be closely examined.

\section{What Ethics is}

Ethics has been variously defined by philosophers. This is not surprising as philosophy, the discipline of which ethics is a branch, suffers from the lack of univocal definition.

First, ethics can be viewed as a normative science of human conduct. ${ }^{1}$ The branding of ethics as a normative science suggests at once that it differs from the physical sciences in their being descriptive. So, why and how is ethics a normative? Ethics is normative in the sense that it deals with the standard or principles of right and wrong behaviour. It attempts to explain, state and often times urge obedience to a rule. It is a science because it is principle governed endeavour and attempts a systematic study of human conduct. Its study represents an intellectual enterprise, a rational inquiry into human actions, and affairs in the hope of gaining knowledge. ${ }^{2}$

\section{What is Business Ethics?}

Business ethics is one type of applied ethics. Business ethics can be defined as the application of the principles and methods of ethics to solving business problems. The basis of ethics is morality. Morality is seen as an instrument that can be used to examine and correct the pitfalls or wrongs in business. ${ }^{3}$

However, business ethics does not aim primarily to describe the nature of business or to give business advice to persons engaged in business, although discussion on this area, to a large extent, influences how business people resolve their problems. Business ethics is concerned with the moral questions that arise in and from the practice of business, and because of the general crisis in modern culture. Business ethics is viewed as a set of guiding principles or rules to practices in any kind of business. These rules serve as rules of conduct in business and business people are expected to conduct their actions in line with the standard. Examples are the rules kept by the standard organization of Nigeria, to which all manufacturing firms are expected to comply. This standard might be regarded as ethics in the sense of rules of conduct. Similarly, many businesses have created "Code of Conduct" which are lists of what they believe to be ethical behaviour.

Furthermore, business ethics can be understood from a philosophical standpoint as an ethical/philosophical inquiry into the conducts and 
practices in business. It is a moral evaluation of practices in business. It addresses such issues as how moral obligations may conflict with profitmotive and how these conflicts may be resolved. As a branch of ethics, it thus requires an understanding of general ethical theories, and practices in business. Business ethics in this sense, aims at assisting business people deal with moral problems arising in the course of their duties. Business does not, however, operate in a vacuum. It is a sub-system of our social order and as such as not immune to the changing social ethics. Business ethics equally is not static but reflects changes and demands arising from new social ethics as it affects business. ${ }^{4}$

\section{The Role Ethics Play in Business}

It is commonplace hearing people say ethics is of little relevance to business, or put succinctly that there is no morality in business, since allmotivating consideration in business is profit. It is said that "ethics is ethics and business is business". The implication of this saying is that ethical issues do not matter in business. This view, though widely held, is fundamentally mistaken. In this vein, it has been argued that the business of business is serving society not just making money. Profit is and should be seen as reward for serving society well. It follows that profit is the means and the measure of our service and in no way is it an end in itself.

One functionalist view of the purpose of business is to serve the public interest. Some companies in America in the $20^{\text {th }}$ century had permission to do business on the grounds that the existence of such firms promoted the public interest. Hence, from this point of view, the first and primary step in moral evaluation of business practices is to ascertain the function and purpose of business. Those business practices which are in accord with the function of business are good business practices. This ascertaining the purpose of business and the practices that confirm to good business practice is one of the primary problems of business ethics. ${ }^{5}$

In business ethics, there is equally the question of social responsibility. The argument here is that corporate officials have a social responsibility that goes beyond serving the interest of their stakeholders. Opposing this view is the idea that in a free market economy, there is only social responsibility of business namely; using its resources and engaging in activities aimed primarily at increased profits so long as it stays within the rules of the game. But the question is, if business does have a social responsibility, other than making profit, is this responsibility a business outfit has to perform?

Another issue in the area of social responsibility is the claim that business should contribute to the support of charitable activities. Two arguments are usually advanced 
against this view namely: that if a corporation makes such contributions, it prevents an individual stakeholder from deciding himself how he should dispose of his funds. Secondly, if this is to happen then corporate tax must be abolished. ${ }^{6}$

\section{Ethical Standards and Business Effectiveness}

How do ethical standards of a firm affect its effectiveness as an economic agent? Does honesty pay? Some people argue that ethics is far from the point of view of upholding one's personal standards, but that from the view of business effectiveness it makes no discernible difference. To back this view they point out that often firms which seem honest do not succeed in business, while firms that seem to disregard ethical issues may be quite profitable.

There is no denying of such observations. However, all that they tell us is that honesty, by itself, does not guarantee business success. But one should remember that brilliant strategy, consistent service to customers, or first class financial management, each by itself, does not guarantee business either. Business success is the product of the complex interaction of many factors. Any one factor can only contribute to it, not guarantee it.

The relevant question is whether consistent ethical behaviour, of itself, contributes positively to business success. It seems clear that it does so by fostering three key ingredients of that success. ${ }^{7}$ Ethical behaviour contributes to the good reputation of a firm and to other parties being ready to trust it, and it promotes commitment to success of the firm. ${ }^{8}$

Besides, contributions to business success, these factors also have the highly desirable characteristic of not easily imitable and therefore can provide a sustainable competitive advantage. New products or services, organizational structures, compensation policies, exploitation of new markets, possession of valuable assets, are all factors that can provide a competitive advantage.

\section{Instilling Ethical Standards in Organizations}

It is not rare for the top decision makers of business companies to want to ensure that their subordinates behave ethically whenever they act on behalf of the company. But it is one thing to wish that one's subordinate behaves ethically and quite another to achieve it.

There are many obstacles on the way to getting an organization to behave ethically. The basic one is that managers are primarily judged and rewarded according to the results they obtain, often short-term results. What happens when a manager feels that most expedient way to attain the results that are expected from him is unfair to some people such as employees, customers or the local community, or otherwise unethical? 
In the first place, such a manager is likely to have a difficult time trying to articulate her case. Economic results like market share, sales, objectives or cost levels are clear and specific, and their relevance to the success of the company obvious. On the other hand, ethical standards tend to seem much more "wholly" and subjective, and therefore they are hard to defend. The manager will fear, and often reason. So, that if she pleads ethical qualms to her superior as a reason for having failed to attain the results expected of her, she will be perceived as offering lame excuses for non-performance. What is likely to happen? Experience shows that in many occasions ethical concerns will take a backseat to immediate economic imperatives, the manager will swallow her ethical qualms and endeavour to obtain the results demanded of her.

But did we not argue before that in the long term, the erosion of ethical standards in an organization will not only cause harm to others but is also likely to undermine the capacity of the organization to perform? We did, in fact, in many cases, it is precisely the fear for such long-term consequence for the organization, which will have prompted the concern of top management to preserve high ethical standards.

In a small company, if top management is competent and is sufficiently committed to ethical behaviour, no special efforts may be required to achieve this. Top managers

convey through their words and example the standards they expect others to live up to, and they are always at hand to ensure that appropriate procedures are followed and to give more specific guidance whenever this may be needed.

In a large company, however, more formal efforts are needed to ensure consistent ethical behaviour throughout the organization. Something that can be done is to draw up an ethical code which spells out the main ethical norms to which the company is expected to adhere in its operations. ${ }^{8}$

\section{Conflicts of Interest in a Business Organization}

Perhaps, a simple example will be of help in clarifying the concept of conflict of interest.

The service manager of a bank has to sell a one-year old Peugeot 505 car which is no longer needed by the bank. Part of this responsibility in this talk is deciding the price that the bank will accept for the car as he needed a vehicle he decides to buy himself, in his personal capacity, the car that the bank is selling.

In this situation, there is clearly a conflict between the responsibility of the manager in his capacity as service manager of the bank (i.e. to get the highest price reasonably obtainable for the car), and his personal interest (to buy the car at the cheapest possible price). 
While most of the situations, which arise in real life, are not as helpfully obvious as the example just considered. It is the presence of the conflict between personal interest and official responsibility which creates the ethical problem that is referred to as a conflict of interest.

A person placed in such a situation could take advantage of it to obtain a car at much lower price than would obtain in an arms-length situation. Very few people are likely to entertain doubts about the ethical quality of such an action, it constitutes a clear-cut case of abuse of fiduciary powers and a close equivalent to a situation of outright theft.

However, the mere fact that the manager finds himself in such a position already places him in a situation of potential conflict of interest; even if in fact he were to bend over backwards in order to avoid taking advantage of the situation and paid above market value of the car. As we will see, there are strong reasons to avoid being placed in such situation of potential conflict. ${ }^{9}$

\section{The Responsibilities of a Business Organization: to Customers, Employees and Society (If Any)}

People often speak of the "responsibilities of the firm" or in a more common phase, of the "social responsibilities of companies". These expressions are often used very loosely and are given different meanings by different speakers. Therefore, it will be useful to engage in some preliminary clarifications.

Some people assert that business organizations have responsibilities which go beyond making profits. Often what they have in mind is that it is proper for companies to support worthy community initiatives like (universities, museums or hospitals) to reduce a minimum pollution, going voluntarily beyond the standard set by the law; to employ the physical handicapped; to refuse to invest in certain places in order to foster political objectives; and generally to use their resources or restrict their activities in ways which are not calculated to maximize their profits but which will contribute to the common good of the communities in which they operate.

Other people reject outrightly the above position and argued that the only responsibilities of a business are to obey the law and make profits for its shareholders. Still others think that companies can legitimately concern themselves with some of the causes listed above

but not with others. ${ }^{10}$

\section{Summary}

The paper has examined the relevance of ethics to business. A business outfit cannot function effectively without taking into consideration the concept of morality. It sees ethics as a moral evaluation of practices in 
business. The paper gives an introductory insight into the meaning of business, ethics and business ethics. It equally considers some of the fundamental principles needed in the administration of any business outfits. It further addresses such issues as how moral obligations may conflict with profit motive and how these conflicts may be resolved. Because it is an organized discipline, business ethics presents more coherent demands. As a branch of ethics, it thus requires understanding of general ethical theories, and practices in business. Business ethics in this sense aims to assist business people deal with moral problems arising in the course of their duties. This paper explains that business does not, however, operate in vacuum. It is a sub-system of social order as well as a large society. It also expatiates on how the ethical standards of a firm affect its effectiveness and how these standards could be instilled in workers in order to behave ethically whenever they are carrying out official responsibilities in their work.

To this end, the issue of social responsibilities of firm has been seen in this paper as not binding on firms because the main purpose of running a business outfit is to make profit and not to use the resources to develop communities where firms are situated.

\section{Conclusion}

From the foregoing, we can see that without morality, human relationships in general and in business environment will become a makeshift of some kind. The relevance of ethics to business cannot be underestimated. If morality is removed from business, there will be problems namely: embezzlement, over-invoicing, untruthfulness, mistrust, non-obedience to higher authority, corruption of some sorts, falsification of official documents, forgery and perjury and a host of others, just to mention a few. The aftermath of this will lead to the eventual collapse of the business. It is worthy to note that most of the reasons for failure in businesses in Nigeria and overseas today are caused initially not by economic problem, but a moral one. Examples are the fraudulent acts that occurred in Cadbury ENRON Nigeria some years back (over-invoicing). However, the development of corporate governance is a reaction to unethical business practices in corporate organizations such as tampering with financial statements to give false impression of the financial health of organizations (companies) to the recipients of reports.

To this end, from a moral problem we now have economic problem. To ensure a smooth running of any business, morality should not be handled with levity. 


\section{Recommendations to Entrepreneur}

i. An entrepreneur must take account of the fact that human beings are end in themselves. They should not be used as means to other ends, desirable or not.

ii. An entrepreneur must not attempt to dehumanize or denude the humanity of others, in pursuit of pecuniary interests. Human beings deserve respect. Simply because they are human, not because they are wealthy or poor, manager or messenger.

iii. An entrepreneur should do nothing to undermine the respect we all earn in virtue of our common humanity.

iv. The dignity and integrity of others should be promoted, protected and ensured in business.

v. An entrepreneur who cannot be trusted, especially by colleagues and the public in general cannot succeed.

vi. An entrepreneur must endeavour to avoid breaking promises just for the fun of it. Doing so repeatedly can lead others to conclude that one is insincere, unreliable and unserious, and not worthy of the trust of others.

vii. The Golden Rule applies in all human situations. What you do not want done to yourself, do not do unto others, is a universal principle. An entrepreneur who does not bother about the import of this principle may not be able to maintain credible, lasting and meaningful business relationships with business associates. Without this relationship, an entrepreneur has no chance of succeeding. ${ }^{11}$

\section{References:}

N. Otakpor, "Ethics and Entrepreneurship" cf. A.U. Inegbenebor, ed., The Fundamentals of Entrepreneurship, (Lagos: Malthouse Press, 2006), 65.

F.J. Aguilar, Managing Corporate Ethics, (New York: Oxford University Press, 1994), 20.

P.K.E. Good, "Ethical Imperatives and Corporate Leadership" cf. R.E. Freeman, (ed.) Business Ethics: The State of the Art, (Oxford: Oxford University Press, 1991), 2.

P.K.E. Good, "Ethical Imperatives and Corporate Leadership" cf. R.E. Freeman, (ed.) Business Ethics:, 2.

J.L. Beranchamp and N. Bowie (eds), Ethical Theory and Business, (Englewood Cliffs: N.J. Prentice Hall, 1993), 20.

J.L. Beanchamp and N. Bowie (eds), Ethical Theory and Business, 20.

R. Beehler, Moral Life, (Oxford: Basil Blackwell, 1979), 14.

W.J. Banmol, Business Behaviour, Value and Growth, (ed) New York: Oxford University Press, 1987), 10. 
H.Angle and J. Perry, "An Empirical Assessment of Organizational Commitment and Organizational Effectiveness". Administrative Science Quarterly, 26, 1981, 1-4.

Allied Research International. The views of Shareholders on Donations by Companies to Charity: Report to the Charities Aid Foundation London: HMSO Books, 1985, 5-10.

N. Otakpor, "Ethics and Entrepreneurship" cf. A.U. Inegbenebor, ed., The Fundamentals of Entrepreneurship, 12-15. 